\title{
The Role of Traditional Leaders in Mitigating Violence and Enhancing Peace and Harmony in Nigeria
}

\author{
Suleiman Danladi Hamza, Sivamurugan Pandian, Razlini Mohd Ramli
}

\begin{abstract}
Violence is a global phenomenon which exists the world over. The form and manner it exists vary from one country to the other. Nigeria has been facing serious challenges of violent acts since her independence till date. These violent acts range from ethno-religious crises, communal conflicts, Boko Haram crisis, Niger-Delta Militancy, farmer/herder clashes among others which threaten peace and harmony in the country. This study examines the role traditional leaders play in mitigating the excesses of violence and enhancing the peace and harmony in Nigeria. The study predominantly relied on secondary data that include journal articles, books, newspapers, etc. In the case of analysis of data, content analysis was employed. The findings reveal that traditional leaders play an important role in reducing the violent acts and enhancing peace and harmony by a way of intervening in resolving conflicts such as farmer/herder clashes, Niger-Delta crisis and so on. Finally, the study suggests that government should empower more the traditional leaders by involving them in the resolution of conflicts and peace talks.
\end{abstract}

Index Terms: Violence, Rise of violence in Nigeria, Traditional leaders.

\section{INTRODUCTION}

Violence is a global phenomenon that exists the world over [1]. However, the form and way it exists vary from one country to the other [2]. Nigeria is the Africa's most populous country with an estimated population of about one hundred and ninety million people [3].

After her independence, the country has been facing a range of violence from ethno-religious conflicts, civil war, Biafran crisis, Meitatsine, etc. These crises have caused the destruction of lives and properties and threatened the peaceful co-existence of the people in the country [1].

Moreover, in recent time, there emerged the crises of Boko Haram insurgents in the Northern part of Nigeria, Niger-Delta Militants in the South-south region, and Farmers/Herders clashes which pose serious challenges to the security, economy, and peaceful co-existence of the country. For example, from 2009 to date the crisis of Boko Haram has accounted for the death of about 20,000 people,

Revised Manuscript Received on September 22, 2019

Suleiman Danladi Hamza, School of Social Sciences Universiti Sains Malaysia

Sivamurugan Pandian, School of Social Sciences Universiti Sains Malaysia,psiva@usm.my

Razlini Mohd Ramli, School of Social Sciences Universiti Sains Malaysia. displaced over two million people and caused the economic setback of the North-east and the country at large [4]. Consequently, the Farmer/Herders clash in Nigeria has according to Amnesty International led to the death of more than 3600 people from 2016 to 2018 [5]. In response to curtail these crises, the government devised means which include the crackdown using security forces such the Military, Police, DSS and so on. Despite a remarkable improvement of the situation in recent years, the Global Peace Index (2018) ranks Nigeria 148 position out of 163 around the world [5]. This shows that the crises are still alarming which place Nigeria among the most violent countries around the world. Thus, this situation has prompted agitations and interest to incorporate the traditional leaders to help in the resolution of such conflicts and other issues that can lead to the peaceful co-existence in the country[7-10].

Traditional leaders in Nigeria have been playing an important role in mitigating violence and ensuring the peaceful co-existence of the people in the country right from pre-colonial period. For example, during pre-colonial period, the traditional leaders were the repository of the executive, legislative, and judicial powers who implemented and maintained law and order, allocated land, resolved conflicts especially land disputes and ensured peace and harmony among people in their respective areas of the domain [11]. As a result, violence particularly ethno-religious conflicts, intra and inter-communal conflicts were minimal [12]. Moreover, during the colonial period, the British colonial masters recognizing the position and the legitimacy and respect the traditional leaders enjoyed in the country, they harnessed them to maintain law and order in the country for the smooth running of the colonial administration in Nigeria.

Even though after the independence of Nigeria, traditional leaders no longer wield executive, legislative, and judicial powers they used to wield during pre-colonial periods, the government, Non-governmental organizations and the public are referring to them on social issues such as the resolution of conflicts and disputes [11]. This is because of the role they have been playing and can play in mitigating these challenges which pose a threat to peace and harmony in the country. 
The basic questions for this study are: What roles traditional leaders play in mitigating violence in Nigeria? How have these roles enhanced peace and harmony in Nigeria? Against this backdrop that this study examines the roles of traditional leaders in mitigating violence in Nigeria.

\section{LITERATURE REVIEW}

This paper discusses the role of the traditional leaders in mitigating violence and enhancing peace and harmony in Nigeria. Moreover, this section has been divided into four: The first section deals with the definition of violence. The second section discussed on the violence in Nigeria and different measures taken by the successive governments to curtail it. Thirdly, the roles of the traditional leaders during pre-colonial and the colonial period were highlighted. Finally, the roles of the traditional leaders were discussed in relation to mitigating violence and enhancing peace in Nigeria.

\section{A. Violence}

First and foremost, there is a need to understand what the concept of violence is all about. Violence is a word which its verb form means to violate. To violate connotes different things; to injure, disobey, defy, disregard, disrupt, encroach, err, infract, infringe, meddle, offend, oppose, outrage, sacrilege, tamper with, transgress, trespass, abuse, invade, pollute, ravish, etc. Each of these constitutes the meaning of violence [2]. Violence has been defined from different angles. In simple term, violence means the use of intense force, often with the use of some weapons to coax or threaten or fatally harm others in order to get them to surrender their properties, or even their lives. The World Health Oganization (n.d.) defines violence as "the intentional use of physical force or power, threatened or actual, against oneself, another person, or against a group or community, that either result in or has a high likelihood of resulting in injury, death, psychological harm, maldevelopment or deprivation". This implies any act (either physical or non-physical) by an individual or group that can cause harm or deprive the others in their life endeavours. It also signifies that any human actions that can lead to destruction or harm to the lives and properties and peaceful co-existence of the other people. Moreover, there are different forms of violence which range from physical, psychological, sexual, spiritual, emotional, and cultural.

\section{B. Violence in Nigeria}

Of course, violence is a global phenomenon which is not peculiar to Nigeria. However, there are different forms of violence, but physical violence is the main concern of this paper. Even though Nigeria has been experiencing almost all forms of violence mentioned above. Historical evidence has shown that Nigeria has been facing a range of violence from ethno-religious conflicts, civil war, Maitaatsine among others [14]. It has also been proved that after the independence of Nigeria, almost all regions in the country have been faced with one or the other forms of violent acts. For example, the Northern part of the country has faced violence such as Maitatsine crisis, several ethno-religious clashes between Hausa and Igbo in Kano, Jos riot in 2001, the Bauchi riot in 1994, the Taliban crisis in 2004 in Yobe State and more recently the crisis of Boko Haram, Armed Bandits, kidnapping, and Farmers/Herders clashes [9]. These crises have led to the death of thousands and displacement of millions of people and the destruction of economic activities in the region and Nigeria at large. It also aggravated the insecurity and heightened the level of violence in Nigeria [15]. According to the National Bureau of Statistics Nigeria [NBS] (2019) the crisis of Boko Haram from 2009 to date has negatively affected about fifteen million people out of which more than 20,000 people have lost their lives. On the other hand, the Amnesty International Report (2018) indicates that the conflict of Farmer/Herder in the Northcentral part of Nigeria has claimed the lives of more than 2000 people in 2018 alone. However, most of the causes of these crises are related either directly or indirectly to the issues of poverty, unemployment, ethnicity, ideology, poor governance, neglect, human right violation among others $[14,15,17]$.

However, the South-South region is the region that Nigeria earns the most from oil revenue. Evidence shows that since the discovery of oil in the region, the region has been facing conflicts and crises that resulted from the struggle for control of oil wealth [18]. Okene (2011) observes that before the discovery of the oil (petroleum resources) in the region, the inhabitants were mainly fishers and farmers. However, with the discovery and the start of the exploration of oil in the region, there exist environmental pollution and degradation which made farming and fishing activities impossible. However, government and the oil companies have not done enough to provide employment opportunities and social infrastructural services that would compensate the people in the region. As a result, there has been the prevalence of poverty, unemployment, and lack of infrastructural service in the region. In response to their plight, people began peaceful protest which later culminated into violent acts such as attacking of oil companies, vandalization of pipeline, kidnappings, and killings [20]. This situation has caused serious damages to the economy of the country by reducing the daily exploration of the oil in the region. For example, oil production at the zenith of the crises, the exploration of oil has fallen from 2 million barrels per day to 500 thousand barrels (Mohammed, Jackson, \& Aliyu, 2014). In an effort to deal with the security situation in the region, the government employed the use of security forces such as military, police, and other security forces to deal with such crises. Despite the measures put in place to deal with the situation, the crises persist.

Considering the increase in the crises and the damages it posed to the economy and the lives and properties of the people in the region, government in 2009 as a way of resolving the crises, introduced Amnesty Programme [18].

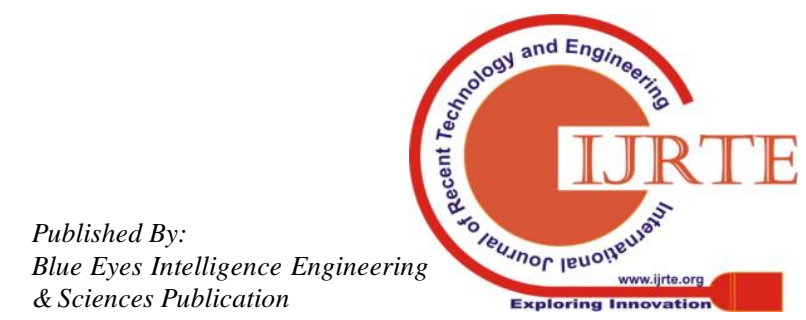


The programme was aimed at giving amnesty to the militants (who surrender their weapons and repent) and provides them with the employment opportunities that will make them productive and rely on their own hence the prevalence of peace and harmony and sustainable development in the region (Ogbonnaya \& Ehigiamusoe, 2013). Amnesty Programme in Niger Delta region has recorded a tremendous success in reducing the incidence of violent acts such as militancy, kidnappings, vandalization of oil pipeline, etc. Despite the success the programme achieved, shreds of evidence indicate that the militant activities of vandalization of oil pipelines, kidnapping, among other have begun to resume [23]. Nweke further states that lack of involving traditional leaders in the programme has resulted in not having a lasting solution to the crises in the region. Thus, he suggested that there is a need to incorporate traditional leaders in the programme and other issues related to the peace process in the region.

Similarly, the Southeastern part of Nigeria has also witnessed series of crises from Biafra crisis, kidnapping, among others. For example, in 1967 the Indigenous People of Biafra (Igbo) desired to have seceded from the Federation of Nigeria [24]. In trying to protect the territorial integrity of the country, the Nigerian military and the Igbo people have engulfed into a war which escalated to a civil war that claimed the lives of many Nigerians. For instance, evidence indicates that about 100,000 military personnel lost their lives in the war and 2 million people died of starvation [25]. This situation has negatively threatened the peaceful co-existence of the people and destructed the economic activities of the country. However, the then military government of Gen. Gowon has tried in reintegrating and bringing back normalcy in the country. Despite the success in truncating the movement of Biafra secession, there has been a resurgence of the crisis from time to time. For example, in 2016, the leader of the Biafran movement has led people in the agitation which resulted in an encounter with the military in which about 150 people have lost their lives [24-26].

\section{The Role of Traditional Leaders During Pre-Colonial and Colonial Periods}

To appreciate the roles of traditional leaders in mitigating violence and ensuring peace in contemporary Nigeria, there is a need to review some literatures on the role of the traditional leaders during pre-colonial and colonial periods. This will appreciate our understanding of the roles of traditional leaders in mitigating violence and ensuring peace in their areas of domain.

Basically, the traditional institution is a type of institution in which the power to rule lies in the traditions, customs, and values of society. It is an indigenous political arrangement whereby leaders are appointed to lead based on tradition and customs of the people. According to Peter (2014, p.135) traditional institution is referred to "indigenous political arrangements whereby leaders with proven track records are appointed and installed in line with the native laws and customs to act as custodian of the people's norms, culture, and practices". This implies that traditional leadership is hereditary in nature and it is not subject to the electoral process. The powers to lead emanate from the custom and tradition of the people.

Historically, traditional leadership existed based on Kingdom, Sultanate, Emirate, and the Empire for the time immemorial before the advent of colonialism in Africa. At that period traditional leaders held executive, legislative, and judicial powers in their respective areas of domain. They provided services, maintained law and order, resolved conflicts, allocated land and ensured peaceful co-existence of their people. For example, Fatile et al (2013) observe that during the pre-colonial period in present-day Nigeria, traditional leadership had an organized system of administration in which traditional leaders wielded executive, legislative, and judicial powers. They implemented and maintained law and order, allocated land, resolved conflicts both "intra and intercommunal", and ensured peace and harmony reigned in their areas of jurisdiction. Fatile further states that the conflict resolution at that time was carried out by the traditional leaders in such a way that the parties involved were invited to a forum whereby they were engaged in negotiation with the aim of resolving their differences mediated by the third party who ensured that reconciliation, cordiality are achieved hence state of hostility was avoided. As a result of the mechanisms employed in the process by the traditional leaders, the occurrence of conflicts which could distort the peaceful co-existence of the people was minimal [12]. Even though, participation and acceptance of such a peace-making process were voluntary. Moreover, Olusola and Aisha added that the successes recorded in the resolution of conflict by the traditional leaders at that period were attributed to the fact that the traditional leaders possessed basic skills, knowledge of the customs, traditions, and values which communities honoured and revered.

Moreover, during the colonial period, traditional leaders continued to wield powers especially with regards to the maintenance of law and order. For example, when British colonists came to Nigeria, they acknowledged the positions the traditional leaders held [11]. As a result, they introduced an "Indirect Rule" which means ruling the colony and the people of Nigeria through traditional leaders and their institutions of governance. At the initial stage, traditional leaders were assigned a role to maintain law and order. This is because at that time there was an uprising against British colonialists by the natives hence a need for peace to be restored so that their colonial administration would be run smoothly in the colony of Nigeria. Considering the legitimacy and respect the traditional leaders enjoyed from their people, British colonists increase their roles and used them as a mechanism for mediating between them and the people [28]. It was however, established that due to the positive role played by the traditional leaders in the 
maintenance of peace and harmony during that period that the colonial administration was successful in colony of Nigeria.

\section{The Role of Traditional Leaders in Resolution of Conflict and Peace Building in Comtemporary Nigeria}

It is apparent that the traditional leaders possess basic knowledge and skills of the customs, traditions, and values of their people and the indigenous patterns of conflict resolution that place them in the better position to play a role in mitigating violence and ensuring peaceful co-existence of the people in Africa. In buttressing this point, different studies examine the impact of indigenous patterns of conflict resolution and peacebuilding in Africa. For example, Osei-hwedie \& Rankopo (2012) in their case study of indigenous conflict resolution in Ghana and Botswana observe that the values embedded in the traditional institutions and cultural processes have a positive impact on the arbitration of conflicts to the extent that people favour the traditional pattern of conflicts resolution than by the courts. This is because the traditional conflict resolution is based on the customs, traditions, and values which are more comprehended, accustomed, and accepted by the people. They concluded that the indigenous patterns of conflict resolution pave a way for peace and harmony to prevail in society. Supporting this argument, Bukari (2013) posits that the modern conflict resolution employed in the case of Bawku conflict in Ghana has failed to resolve the long-age conflict bedeviled the area. He further asserts that the Kusasi and Mamprusi traditional patterns of the conflict resolution can have a positive impact in resolving the conflict hence the prevalence of peace and harmony in the area. Similarly, a study conducted by Sharma (1997) in Botswana shows that traditional customary courts have adjudicated over 75-80\% the criminal and civil cases in the country. These studies emphasize the strength of the indigenous conflict resolution patterns in restoring peace without giving due consideration to its weakness. They also affirm to the fact that people prefer indigenous mechanisms for the resolution of conflict, despite the absence of written laws that could guide the process.

In contrast, Loveness \& Mathew (2017) in their case study on the role of the indigenous knowledge system in peace-building in the Umguza District in Zinbabwe discover that traditional leaders play a significant role in the arbitration of conflict and disputes, however, the process of indigenous conflict resolution has been fraudulent, subjective and politicized. This problem was attributed to the absence of any written law that can guide the process and prevent the traditional rulers to adjudicate according to their personal whim. Therefore, they suggested the need to assign formal role to the traditional institutions in the resolution of the conflict so that the process will be protected against corruption and any other personal interests.

Studies with different approaches in Nigeria have examined the extent to which traditional leaders play a role in resolving a range of conflicts from ethno-religious, farmer/herder clashes, militancy, Boko Haram insurgency among others. For example, Aliyu et al (2016) examined the role played by Kano Emirate in resolving the spate of ethno-religious crises between Hausa and Igbo that faced the state in the past. They found that Kano Emirate has played a vital role in the resolution of such ethno-religious conflicts by using an informal mechanism. As a result, peace and harmony has been restored between Hausas and Igbos in such a way that majority of the people showed preference to the conflict resolution by Kano Emirate over modern patterns by the police and courts in the state. Although the study has proved the legitimacy and respect the Kano Emirate still enjoy from the people in the state, it negates the fact that when conflict becomes violent it must involve the formal pattern (by security personnel like the military and police) of resolving and restoring peace in the situation. Supporting Aliyu et al's argument, Okonji (2016) postulates that the local chiefs contributed in resolving and restoring peace in the case of ethno-religious conflict in Kosofe in Lagos. In addition, he found out that $88.8 \%$ of the respondents of the study acceded to the decisions of the traditional chiefs over other actors in the arbitration of the conflict in Kosofe LGA in Lagos State. This shows that the traditional leaders played a vital role in the resolution of ethnic and religious conflicts and therefore, such conflicts are best handled by them because people honour, respect, and accept their decisions. Similarly, Hamisu, Makinta, Muhammed, Garba, \& Umar (2017) examine the impact of traditional leaders in resolving farmers/herders' conflict in Borno State. They found that majority of the people involved in the conflict believed that traditional leaders played a vital role in resolving the conflict between them. As a result, peace has been restored in the area. This study concluded that the strategy employed by traditional leaders in resolving such conflict contributed in bringing peace and normalcy in the area. This is an empirical case study whose finding can be applied to other parts of the country where such a conflict is taking place.

In their studies Chizea \& Osumah (2015), Nweke (2012), Olusola \& Aisha (2013) argued that most of the crises such as ethno-religious crises, militancy in the Niger Delta, Boko Haram insurgency, farmer/herder clashes, among others occur and aggravate in Nigeria as a result of not involving the traditional rulers at the initial stage of the crises. They further believed that the traditional rulers have the knowledge of values, norms, culture, and traditions of their people with which they can resolve and manage conflicts and crises and ensure peace and harmony prevail in their areas of domain. This assertion is true because evidence in the past (during pre-colonial and colonial periods) has clearly showed that the traditional leaders resolved and managed conflicts effectively and ensured peace reigned in their respective areas of jurisdiction. 


\section{METHODOLOGY}

This study employed the use of secondary data such as Journal articles, government and non-governmental reports, Newspapers, Magazines, etc. through a systematic review. In the case of the Journal articles, relevant empirical and non-empirical index peer-reviewed and non-index peer-reviewed journal articles obtained from library data base, google scholar, and web of science were selected and used for the study. However, predatory journal articles were rejected. In term of analysis, document analysis was carried out for the study.

\section{FINDINGS}

This study has reviewed literatures on the violence acts such as farmer/herder clashes, ethno-religious crises, Boko Haram crises, Militancy in the Niger Delta region, among others in Africa and Nigeria in particular. Based on different studies reviewed, it was discovered that most of the studies both empirical and unempirical on the roles of the traditional leaders particularly on farmer/herder clashes have not covered areas where such conflicts are more pronounced and intensified in Nigeria.

Nevertheless, this study establishes that traditional leaders play a significant role in reducing the incidence of violence of farmer/herder clashes, ethno-religious crises, Boko Haram insurgency, etc. by intervening as intermediary between the parties involved in the conflict. For instance, recognizing the importance of traditional rulers in resolving conflicts and ensuring peace, President Buhari on several occasions calls on them to support the government in curbing violence such as armed banditry in Zamfara and other areas facing similar crises in the country [34]. The findings further prove that traditional leaders still command high legitimacy and respect from their people which enable them to mediate and resolve the conflict between conflicting parties and ensure the prevalence of peace in their areas of domain. Moreover, it has been discovered that lack of involvement of traditional leaders in conflict resolution and peace-building has aggravated the insecurity situation in Nigeria. For example, the Niger Delta Amnesty Programme which failed to bring a lasting solution to the crises and ensure peace-building in the region. On the other hand, the study has found evidence where the involvement of traditional leaders in conflict resolution has led to restoration of peace and harmony for instance, in Kano, Borno, among others. In view of that, this study affirms that the traditional leaders play a significant role in mitigating violent conflicts and ensure peace and harmony in Nigeria despite the lack of formal role in that regard.

\section{CONCLUSION}

It is apparent from the literature discussion that traditional leaders have been very instrumental in resolving violent conflicts and ensuring peace and harmony right from the pre-colonial time up to present time. Thus, this study found that the traditional leaders contributed immensely in mitigating violence and ensuring peace and harmony by intervening in between the people involved in the conflicts and other acts of violence in Nigeria. Therefore, this study concluded that there is a need for the government to assign formal roles to traditional leaders in the resolution of conflict and other social issues that can distort the peaceful co-existence of the people in the country.

\section{REFERENCES}

[1] Irene OF. International Journal of Arts and Humanities ( IJAH ) Violence in Nigeria : Nature and Extent. 2016;5(16):72-85.

[2] Degenaar JJ. The concept of violence. The Concept of Violence. 1980;7(1):14-27.

[3] Nigeria NB of S. No Title [Internet]. 2019. Available from: https://nigerianstat.gov.ng/page/data-analysis

[4] Wilson M. No Title. Nigeria's Boko Haram attacks in numbers-as lethal as ever [Internet]. 2018; Available from: https://www.bbc.com/news/world-africa-42735414

[5] Hague T. Global Peace Index 2018. 2018; Available from: http://visionofhumanity.org/reports

[6] Global Peace Index. Measuring peace in peace in a complex world [Internet]. 2018.2 Available from: http://visionofhumanity.org/app/uploads/2018/06/Global-Peace-Index2018-2.pdf

[7] Bukari KN. Exploring Indigenous Approaches to Conflict Resolution: The Case of the Bawku Conflict in Ghana. J Sociol Res. 2013;4(2):86.

[8] Okonji PI. Traditional Chieftainship in Peace Building and the Ethnic Conflict in kosofe Local Government Area of Lagos State, Nigeria. Int J Sci Res Innov Technol. 2016;3(6):26-37.

[9] Aliyu A, Moorthy R, Idris NA. The role of Kano Emirate council in managing ethnic and religious conflict in Kano state Nigeria. J Soc Sci Humanit. 2016;11(1):1-17.

[10] Mohammed M, Sa'adu H, Faruq B. Influence of Traditional Institutions in Farmer-herder Conflicts Management in Borno State, Nigeria. Asian J Agric Extension, Econ Sociol. 2017;17(2):1-6.

[11] Fatile, J. O., Majekodunmi, A., Adejuwon KD. Traditional rulership in contemporary government system and dilemma of relevance. J Policy Dev. 2013;7(2):72-83.

[12] Olusola O, Aisha A. Traditional Rulers And Conflict Resolution : An Evaluation Of. Commonw J Local Gov. 2013;3(21):120-8.

[13] Oganization WH. Violence-A global health problem [Internet]. Available from: https://www.who.int/violence_injury_prevention/violence/world_report/ en/chap1.pdf

[14] Jāmi‘u M. TACKLING THE NIGERIA SECURITY CHALLENGES : THE ISLAMIC PANACEA. Eur Sci J. 2013;9(8):284-95.

[15] Nwanegbo CJ, Odigbo J. Security and National Development in Nigeria: The Threat of Boko Haram Security and Development: Conceptual Explanations. 2013;3(4):285-91.

[16] Amnesty International: Farmer-Herder clashes kill 3600 people in Nigeria [Internet]. 2018. Available from: https://www.amnesty.org/en/latest/news/2016/11/peaceful-pro-biafra-ac tivists-killed-in-chilling-crackdown/

[17] Okeke-Ogbuafor NA, Gray TS, Stead SM. Reconciling Traditional Indigenous Governance with Contemporary Approaches to Decision Making in Ogoni Communities in Rivers State, Nigeria. J Sustain Dev. 2016;9(1):55

[18] Aminu AS. The Militancy in the Oil Rich Niger Delta: Failure of the Federa Government of Nigeria. Interdisplinary J Contemp Res Bus. 2013;4, No:813-27.

[19] Okene AA. National Security, Good Governance and Integration in Nigeria since 1999: A Discourse. Asian Soc Sci [Internet]. 2011 Sep 29 [cited 2013 Oct 28];7(10):166-76. Available from: http://www.ccsenet.org/journal/index.php/ass/article/view/12461

[20] Godwin, I., Ndukaku, I. \& Emmanuel I. Traditional Ruler, Environmental Education, Pollution and Rural Communities in Nigeria: Challenges and Prospects. Eur J Sustain Dev. 2016;5(2):75-86.

[21] Mohammed SB, Jackson OR, Aliyu IH. From Conflict to Peace Building and Post Conflict Reconstruction: A Critical Reflection on the Nigeria Niger Delta Amnesty. Int Lett Soc Humanist Sci. 2014;30:81-95.

[22] Ogbonnaya, M. \& Ehigiamusoe UK. Niger Delta Militancy and Boko Haram Insurgency: National Security in Nigeria. Glob Secur Stud. 2013;4(3):1-14 
[23] Nweke K. The Role of Traditional Institutions of Governance in Managing Social Conflicts in Nigeria's Oil -Rich Niger Delta Communities: Imperatives of Peace-Building Process in the Post-Amnesty Era EEE. Br J Arts Soc Sci. 2012;5(2):202-19.

[24] Julius-Adeoye RJ. The Nigeria-Biafra war, population culture and agitation for sovereignty of Biafra Nation. African Stud Cent Leiden, Netherlands. 2017;1-21.

[25] Maiangwa B. Revisiting the Nigeria-Biafra: The intangibles of post war reconciliation. Int J World Peace. 2016;XXXIII(4):39-67.

[26] Amnesty International. Nigeria: Atleast 150 peaceful pro-Biafra activists killed in chilling crackdown [Internet]. 2016. Available from: https://www.amnesty.org/en/latest/news/2016/11/peaceful-pro-biafra-ac tivists-killed-in-chilling-crackdown/

[27] Peter I. Reconsidering the place of traditional institutions under the Nigerian constitution: A comparative analysis. J Law, Policy Glob. 2014;31:135-48.

[28] Osakede KO, Ijimakinwa SO. Traditional Institution and the Modern Dayadministration of Nigeria : Issues and Prospects. Acad J Res Econ Manag. 2015;2(9):32-40.

[29] Osei-hwedie K, Rankopo MJ. Indigenous Conflict Resolution in Africa : The Case of Ghana and Botswana. IPSHU English Res Rep Ser. 2012;29:33-51

[30] Sharma KC. Mechanisms for involving traditional leaders in the promotion of good governance. In: Ray, D. I., Sharma, K. \& May-Parker II, editor. Symposium on traditional leadership and local government. Gaberone; 1997. p. 40-4.

[31] Loveness N, Mathew S. The role of Indigneous Knowledge systems in peace building: A case of Umguza District, Zimbabwe. Int J Polit Good Gov [Internet]. 2017; VIII(8.1):1-16. Available from: http://www.onlineresearchjournals.com/ijopagg/art/230.pdf

[32] Hamisu S, Makinta M, Muhammed S, Garba L, Umar S. Perceptional Analysis: Effectiveness of Traditional Institutions in Farmer-herder Conflicts Management in Borno State, Nigeria. Asian J Adv Agric Res. 2017;1(1):1-5.

[33] Chizea BO, Osumah O. Two sides of a coin: Traditional rulership and the mitigation of nonstate security threats in nigeria. African Secur. 2015;8(2):75-95.

[34] Oyeyemi T. No Title. President Buhari urges Traditional Rulers to support fight against criminality [Internet]. 2019; Available from: https://fmic.gov.ng/president-buhari-urges-traditional-rulers-to-support-f ight-against-criminality/

\section{AUTHORS PROFILE}

I am Suleiman Danladi Hamza, currently affiliated with School of Social Sciences Universiti Sains Malaysia. My area of interest is social sciences.

I am Sivamurugan Pandian, associated with School of Social Sciences Universiti Sains Malaysia. My area of interest is social sciences. psiva@usm.my

My name is Razlini Mohd Ramli, currently working with School of Social Sciences Universiti Sains Malaysia, I am like to contribute in social sciences. 